\title{
BIOMARKERS IN PROGRESSIVE CHRONIC KIDNEY DISEASE. STILL A LONG WAY TO GO
}

\author{
Theodoros Ntrinias, Marios Papasotiriou, Lamprini Balta, Dimitra Kalavrizioti, \\ Sotirios Vamvakas, Evangelos Papachristou and Dimitrios S. Goumenos \\ Department of Nephrology and Renal Transplantation, University Hospital Of Patras, Patras, Greece
}

Corresponding author: Dimitrios S. Goumenos, Department of Nephrology and Renal Transplantation, University Hospital of Patras, Patras, Greece. Tel. +30 2613 603361, Fax. +30 2610 994424, Email.dgoumenos@upatras.gr

\section{ABSTRACT}

The traditional chronic kidney disease (CKD) biomarkers (eGFR based on serum creatinine, sex and age and albuminuria) cannot predict a patient's individual risk for developing progressive CKD. For this reason, it is necessary to identify novel CKD biomarkers that will be able to predict which patients are prone to develop progressive disease and discriminate between disease processes in different parts of the nephron (glomeruli or tubules).

A good biomarker should change before or simultaneously with lesion development and its changes should correlate strongly with lesion development. Also, there should be a close relationship between severity of injury and amount of detectable biomarker and its levels should decrease with diminishing injury.

Among the large number of molecules under investigation, we have reviewed the most promising ones: NGAL and KIM-1, MCP-1, MMP-9, clusterin, MMP-9, TIMP-1, Procollagen I alpha 1 and suPAR. All these, have been studied as biomarkers for prediction of CKD progression in cohorts of patients with chronic kidney disease of different stages and various aetiologies (proteinuric and non-proteinuric, glomerulonephritides, diabetic, hypertensive and polycystic kidney disease). There is evidence that these molecules could be useful as biomarkers for progressive chronic kidney disease, however, the available data are not enough to draw final conclusions. Further studies with large cohorts and long follow-up are required to identify appropriate biomarkers, that will be able to accurately and reliably define the risk for progressive chronic kidney disease.

Keywords: chronic kidney disease, biomarkers, interstitial fibrosis

\section{INTRODUCTION}

Biomarkers have served as a useful tool in risk stratification, diagnosis and treatment follow up of many disease processes for many years. The term "biomarker" however first emerged in 1989, when it was defined as a "measurable and quantifiable biological parameter" [1]. Twelve years later the concept of biomarkers evolves further through a second definition provided by an NIH working group report. According to that, a biomarker is defined as "a characteristic that is objectively measured and evaluated as an indicator of normal biological processes, pathogenic processes, or pharmacologic responses to a therapeutic intervention" [2]. Biomarkers in nephrology have been attracting 
a great deal of attention over the last years due to the constant increase in the prevalence of chronic kidney disease (CKD) [3].

Biomarkers could be of use in various aspects of clinical and research activity, as so far it is not possible to accurately assess which patients are more likely to develop CKD. The main risk factors for renal disease are hypertension, diabetes and older age (Figure 1). However none of these exhibit adequate sensitivity or specificity for future renal disease to allow us to estimate a person's individual risk for future development of CKD. A potential biomarker, that is able to predict which patients are more prone to progressive kidney disease in the future, will enable us to target the population most likely to benefit from aggressive treatment and novel therapeutic options. Renal glomeruli and renal tubules both participate in advanced kidney disease. However there are kidney diseases, where the initial insult is primarily glomerular and vice versa. Availability of biomarkers that measure and quantify glomerular and tubular damage in any given time would provide a useful insight in the pathophysiology of different renal diseases. Furthermore, this would be a very useful tool in the development of novel treatments, since the involved areas of the nephron would be more accurately localized, letting us know exactly where our treatment efforts should be directed (Figure 2).

Potentially more than one biomarker could be identified, each one with a different utility; a biomarker could provide information about a patient's individual risk to develop CKD, before kidney disease actually ensues. Secondly, it could serve as a marker of damage for specific areas of the nephron e.g. glomeruli or tubules. Moreover, a biomarker could provide insight on the patient's response to treatment.

The aim of this review is not to cover every potential biomarker investigated. Our aim is rather to focus on the most promising biomarkers for CKD under study.
Predisposing factors for CKD

Age, gender, race and genetics Hypertension

Diabetes

Obesity and low birth weight

Smoking

Low socioeconomic status

Nephrotoxins

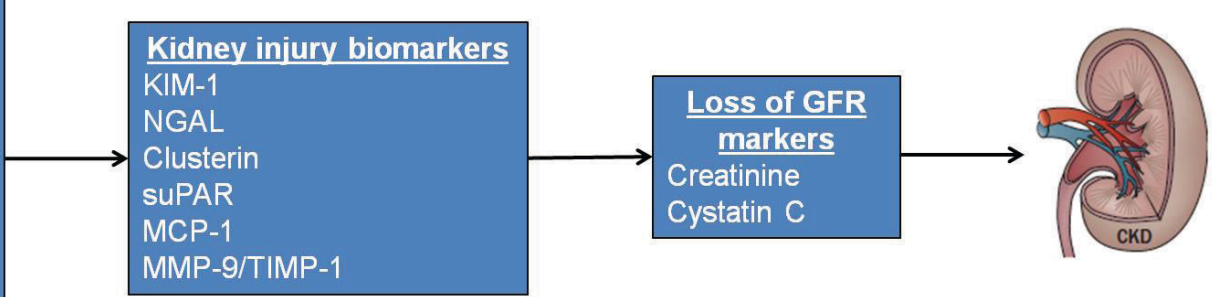
Kidney iniury biomarkers MCP-1 MMP-9/TIMP-1

Fig. 1. Pathway of chronic kidney disease (CKD) development and proposed risk assessment. Predisposing factors can detect candidate patients who are prone to CKD which can then be early identified by kidney injury biomarkers early before the increase of loss of glomerular filtration markers (GFR) like serum creatinine.

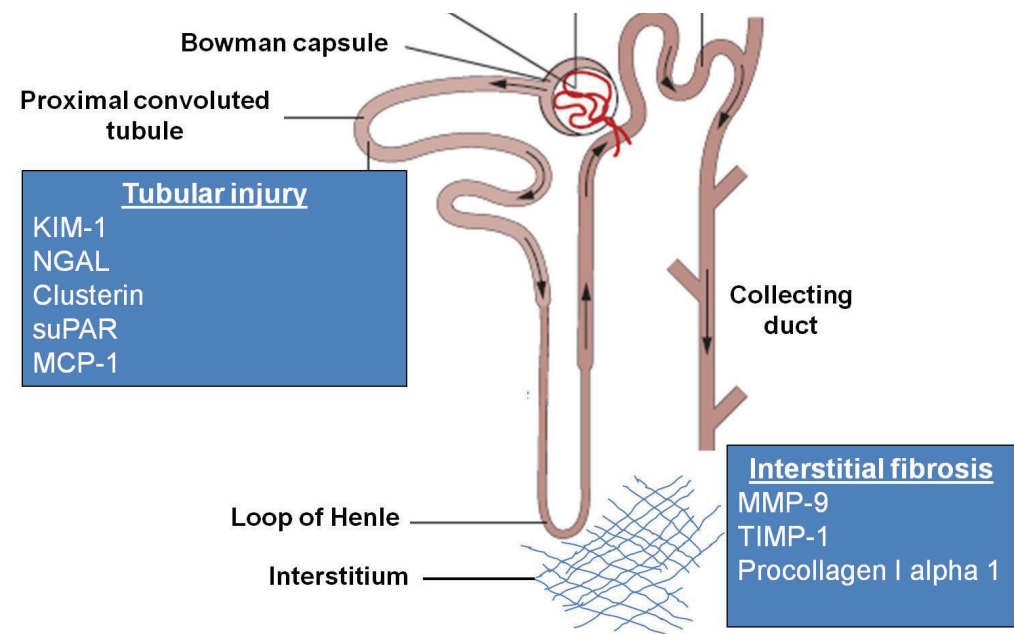

Fig. 2. Kidney injury biomarkers originating along the glomeruli, the tubules and the interstitium. 


\section{CONVENTIONAL AND EMERGING BIOMARKERS}

Conventional biomarkers for CKD mainly include estimated glomerular filtration rate (eGFR) based on serum creatinine and calculated by several formulas (e.g. CKD-EPI) and albuminuria. However, eGFR and albuminuria are only modestly useful as risk predictors and in addition, albuminuria has significant limitations, including regression either spontaneously or after therapy while it is not uncommon for fast CKD progression to occur without high grade albuminuria.

There are four major characteristics of a good predictive biomarker; namely, that (1) biomarker changes occur before or in concert with lesion development, (2) biomarker changes are strongly correlated with lesion development, (3) there is a close relationship between the amount of observable injury and the amount of detectable biomarker, and (4) biomarker concentrations decrease with diminishing injury [4].

Transforming growth factor-Beta-1 (TGF- $\beta 1$ ), alpha-smooth muscle actin (alpha- SMA) and transglutaminase type-2 (TG2) have been subjects of previous investigation concerning CKD biomarkers besides the traditional ones. TGF- $\beta 1$, a fibrogenic growth factor, was studied in a cohort of 40 patients with glomerulonephritis and its interstitial expression correlated with the severity of tubular atrophy, interstitial fibrosis and serum creatinine, while its glomerular expression was related to the degree of glomerulosclerosis [5]. TGF- $\beta 1$ also seemed to be of prognostic significance in an another study that included patients with crescentic nephritis, since patients who failed to respond to immunosuppression exhibited significantly higher urinary levels of TGF- $\beta 1$ [6]. TG2 is a protein that interferes with the homeostasis of extracellular matrix and thus takes part in the process of renal scaring. A study from 2012 showed increased TG2 expression in kidney biopsies of patients with membranous nephropathy compared to controls and this expression correlated with the degree of interstitial fibrosis and glomerulosclerosis. The most important finding, however, was that patients who developed severe interstitial fibrosis over the disease course had increased expression of TG2 at diagnosis [7]. Additionally, interstitial staining of alpha-SMA, the characteristic marker of myofibroblasts, could also discriminate progressors from non-progressors in a cohort of patients with IgA nephropathy [8]. Nevertheless, all the aforementioned biomarkers were validated mainly in kidney biopsy cohorts, restricting their utility only in those patients with an indication for kidney biopsy, which represent merely a small fraction of patients with CKD.

Herein, we highlight the next generation of emerging biomarkers detected in urine and serum that have been associated with CKD progression and validated in multiple cohorts.

\section{KIDNEY INJURY MOLECULE-1 (KIM- 1) AND NEUTROPHIL GELATINASE ASSOCIATED LIPOCALIN (NGAL)}

KIM-1 is encoded by the HAVCR 1 gene and it is a type 1 transmembrane glycoprotein. It consists of an extracellular immunoglobulin-like domain, a transmembrane and an intracellular domain $[9,10]$. In humans two homologs of the protein are encountered, named KIM-1a and KIM-1b. KIM-1b is the type located in the kidney $[6,11,12]$. KIM-1 is found in low levels in normal kidneys, however, shortly after various types of renal tubular injury, such as ischemia-reperfusion injury and drug related renal toxicity $[5,13]$, an increase in its renal expression occurs.

The S3 segment of the proximal tubule has been identified as the site of KIM-1 expression after kidney injury [14]. The membrane bound domain of KIM-1 is separated from the cell surface into the extracellular space as well as the urine. This metalloproteinase-dependent process, results in the appearance of a $90 \mathrm{kDa}$ peptide in the urine $[15,16]$. Therefore urinary levels of KIM-1 rise after renal tubular injury and besides increased shedding, this probably has to do with upregulated intrarenal synthesis $[17,18$, 19]. The exact role of KIM-1 remains to be identified. The use of KIM-1 as a potential biomarker for timely recognition of renal tubular injury is now recognized, especially since its expression correlates with the degree of interstitial fibrosis and inflammation of the affected kidney [5, 20, $21,22]$. Apart from its pathophysiological roles, the main characteristics of KIM-1 that make it an attractive biomarker are the following: it is absent from the normal kidney, it is abundantly and persistently expressed in the injured kidney throughout the course from injury to recovery and the detectable soluble ectodomain measured in urine is stable at room temperature $[16,24]$. 
NGAL, also known as siderocalin, lipocalin-2 or lipocalin is encountered in various locations in the human body. The main sights of its expression are white blood cells, the loop of Henle and the collecting ducts [23, 24]. It is encoded in the Lcn 2 gene [25] and its production is triggered by tissue injury. It exhibits anti-bacterial properties through iron-scavenging processes [26, 27] and its expression after activation of the epidermal growth factor receptor results in increased cell proliferation, cytogenesis and damage to the kidney [28]. NGAL seems to have a beneficial impact on acute kidney injury but in CKD it may participate into mechanisms of its progression [25].

KIM-1 as a potential biomarker for the identification of patients at risk for progression of $\mathrm{CKD}$ has been investigated in various populations. In a large cohort $(\mathrm{N}=1472)$ of the REGARDS study [25] including patients with eG$\mathrm{FR}<60 \mathrm{ml} / \mathrm{min}$ and albuminuria (ACR $>30 \mathrm{mg} / \mathrm{g}$ ), urine NGAL and KIM-1 concentrations were associated with all-cause mortality and progression to ESRD. Furthermore, urine KIM-1 correlation to ESRD remained statistically significant even after adjustment for eGFR [29]. Seibert et al, prospectively studied the use of urinary NGAL and KIM-1 as prognostic biomarkers in a stable CKD population ( $\mathrm{N}=143$ ), including patients with diabetic and hypertensive nephropathy, autosomal dominant polycystic kidney disease and glomerulonephritis/vasculitis. None of the two biomarkers achieved to predict $\triangle \mathrm{eGFR}$ and $\triangle \mathrm{ACR}$ for a follow-up period of 37 months. However a significant association with $\triangle \mathrm{eGFR}$ was found in the glomerulonephritis/vasculitis subgroup [30]. A study from China examined the association of KIM-1 with renal lesions and renal outcomes in lupus nephritis patients and identified the combination of UNGAL and uKIM-1 as an independent risk factor for renal outcomes [31]. Another large $(\mathrm{N}=1982)$ prospective study from England, including patients with CKD stage 3 and 4, evaluated baseline blood levels of KIM-1 and NGAL as potential markers for the identification of patients at risk for progression. Whereas both NGAL and KIM-1 were found to be independently associated with a greater risk for ESRD (HR 1.25; 95\% CI, 1.10 - 1.43 and HR $1.35 ; 95 \%$ CI, 1.14 - 1.59, respectively), their addition to the initial risk model did not significantly improve model discrimination or risk reclassification [32]. KIM-1 has also been studied in patients with diabetic nephropathy. Normoal- buminuric and microalbuminuric patients with type 2 diabetes seem to exhibit higher uKIM1 levels [33] and serum and urine KIM-1 levels are high among rapid progressors [34, 35]. Moreover macroalbuminuric patients with type II diabetes who progress to serious CKD have significantly higher levels of urine KIM-1, but KIM-1 could not predict progression to ESRD independently from albuminuria [36].

In a study by Smith et al. [37] with 158 CKD stage 3 or 4 patients, measurement of urinary NGAL improved the ability to predict the deterioration of renal function. Specifically, urine NGAL to creatinine ratio was found to correlate well with risk of death and progression to dialysis. Apart from urinary NGAL, blood levels of NGAL seem to be of significance as well. In a study of 96 adult patients over a period of 18.5 months by Bolignano et al. Patients with serum NGAL more than $435 \mathrm{ng} / \mathrm{ml}$ exhibited significantly worse renal survival than those with levels below $435 \mathrm{ng} / \mathrm{ml}$. Urinary levels of NGAL correlated with progression of kidney disease as well [38]. NGAL has also been studied in children populations as a CKD biomarker. In a study including 45 children with CKD of various stages, plasma NGAL exhibited inverse association with GFR and performed better than cystatin C when GFR dropped below 30m1/min [39].

\section{MONOCYTE CHEMOATTRACTANT PROTEIN 1 (MCP-1)}

MCP-1 belongs to the family of the C-C chemokines and is was the first member of the family ever identified in humans [40]. Its gene resides in chromosome 17 , it serves as a strong chemotactic factor for monocytes and its molecular weight is $13 \mathrm{kDa}$ [41]. The production of $\mathrm{MCP}-1$ takes place in a wide range of cell types [42] and it may be the consequence of stimulation by oxidative stress, cytokines, or growth factors; nonetheless monocytes/macrophages are the major site of origin of MCP-1 [43].

In the kidneys, MCP-1 is mainly produced by tubular epithelial cells and it is implicated in the development of interstitial inflammation and fibrosis, a process invariably present in all types of renal disease [44]. Urinary excretion of MCP-1 has been studied as a potential predictor of the degree of kidney fibrosis in IgA nephrop- 
athy patients. In this particular study, 58 patients were included and urine levels of MCP-1 along with those of EGF, IL-6 and TGF $\beta 1$ were found to provide significant additional non-invasive information that significantly improved the prediction of the extent of interstitial fibrosis [45]. Moreover, MCP-1 has been studied in patients with other types of primary GN as well $[46,47]$. A study of 58 patients with primary GN of various types showed that urine EGF/MCP1 ratio, but not MCP-1 urine levels alone, was independently associated with interstitial fibrosis/tubular atrophy (IFTA) severity [39], whereas urinary excretion of MCP-1 normalized for urine creatinine was associated with active tubulointerstitial inflammation in another cohort of 32 patients with primary GN [40]. Additionally, higher pre-donation levels of MCP-1 in the urine of 634 living kidney donors were correlated to increased IFTA [48]. In kidney transplantation, MCP-1 has been exhibited to be of value in the prediction of development of chronic allograft nephropathy in two studies from a Canadian center. In 111 kidney transplant recipients, urinary levels of MCP-1, 6 months after surgery, were able to independently predict IFTA development or inflammation 24 months after surgery $[49,50]$. Finally, urinary levels of MCP-1 were measured in 43 patients with diabetes type 1 and diabetic nephropathy, defined as eGFR $<60$ $\mathrm{ml} / \mathrm{min}$ and albuminuria $>300 \mathrm{mg} / 24 \mathrm{~h}$, and compared to a control group of patients with diabetes type 1 without evidence of kidney disease in a cross-sectional study. Patients with albuminuria and reduced eGFR had significantly higher urinary levels of MCP-1 compared to controls, a finding that supports the concept that tubulointerstitial damage is a key component of diabetic nephropathy [51].

\section{CLUSTERIN (CLU)}

CLU is a $75 \mathrm{kD}$-disulfide-linked heterodimeric glycoprotein with multiple biologic functions involving cell adhesion, apoptosis, DNA repair, tissue remodelling and membrane recycling. CLU protein is highly expressed by the TGF- $\beta$ signalling pathway in renal tubular epithelia after renal injury and can be deposited in the kidney as a component of immune deposits [52]. Its molecular size prevents its filtration in the kidney (that is, urinary levels are specific to kidney injury), and increased urinary levels have been reported after renal ischemia or exposure to various nephrotoxins, presumed to represent damage to the proximal and distal tubules $[53,54]$.

Urine CLU is increased in acute kidney injury in both human patients of different ages $[55,56]$ and rats [57] in experimental models, where it performs best in the acute injury phase. More importantly, in these studies urine CLU outperformed urinary albumin as a marker of kidney injury. Moreover, baseline CLU concentration has the potential advantage of predicting the loss of residual renal function in CKD-Vd patients treated with peritoneal dialysis, independent of the peritoneal dialysis solution used [58]. These findings become even more important as baseline albuminuria in most cases cannot predict residual renal function decline in CKD-Vd as opposed in patients with other grades of CKD [59, 60]. In patients with diabetes, urine CLU shows a positive correlation with the annual rate of decline of eGFR. In a prospective study of 159 patients with type 2 diabetes urine CLU correlated with the development of CKD 3 or greater and the progression of albuminuria. Moreover, in this study, urine CLU showed a significant correlation with other urine tubular damage markers like KIM-1, LFABP and NGAL [61]. Despite these promising results, in another study in patients with diabetes, urine CLU showed a lower overall sensitivity and specificity in comparison to urinary NGAL in predicting diabetic kidney disease, although urinary levels of CLU were significantly higher in patients with established diabetic kidney disease [62]. Overall, urine CLU is a reliable candidate for CKD validation with the prospective of predicting CKD progression.

\section{MAMMALIAN MATRIX METALLO- PROTEINASES-9 (MMP-9)}

There are 25 members of reported MMPs [63] which are important key regulators of extracellular matrix (ECM) turnover by remodelling and degrading ECM components. MMPs are endogenously inhibited by the tissue inhibitors of metalloproteinases (TIMPs: TIMP1-4). All TIMPs inhibit pro and active MMPs with relatively low selectivity. 
Ten members of MMPs (MMP-1, 2, 3, 9, $13,14,24,25,27,28)$ are expressed in the kidney. In experimental models of kidney fibrosis, MMP-9 is produced from mesangial, glomerular, epithelial and endothelial cells, fibroblasts and macrophages in the kidney [64]. Renal MMP-9 is at low levels in the absence of pathology while advancing age causes decreased MMP-9 and increased TIMP-1 expression, which contributes to the decline in collagen degradation [65]. MMP-9 processes a variety of ECM substrates such as collagens, elastin, fibronectin and others; nonECM substrates and even other MMPs (MMP-2 and MMP-13) and itself.

MMP-9 is elevated in a variety of kidney disease models and in humans, including patients with IgAN, Henoch-Schönlein nephritis (HSN), nonIgA mesangial proliferative glomerulonephritis, lupus nephritis, and Alport syndrome [66]. In addition, MMP-9 is co-localized in scattered neutrophils within diseased glomeruli in acute post-streptococcal glomerulonephritis [59]. In children with HSN, urinary MMP-9 levels are found significantly higher in comparison to controls and patients with just Henoch-Schönlein purpura [67]. In another study in children with CKD, urinary MMP-9 levels were significantly higher in comparison to controls, though, despite that, this study was not able to prospectively show a correlation of this finding with progressive CKD [68]. Moreover, in a study of patients with type 2 diabetes, urinary MMP-9 was significantly increased in both non- and albuminuric patients in comparison to normal controls. Additionally, MMP-9 was positively correlated to $\mathrm{HbA} 1 \mathrm{c}$ levels, indicating an association with those patients with uncontrolled diabetes who are also in increased risk for developing diabetic nephropathy [69]. Concerning urinary MMP-9 levels in glomerulonephritides, in 32 patients with ANCA associated vasculitis, urinary MMP-9 was not higher in comparison to controls although urinary MMP-9 activity was significantly elevated and MMP-9 glomerular expression correlated positively with fibrinoid necrosis and cellular crescents [70]. In patients with minimal change disease urinary MMP-9 was not elevated in comparison to controls, but on the contrary in focal segmental glomerulosclerosis urinary MMP-9 was significantly increased [71] and correlated with NGAL urine excretion.

\section{TISSUE INHIBITOR OF METALLO- PROTEINASES - 1}

The amount of interstitial fibrosis and glomerular sclerosis is the result of a balance between synthesis and degradation of collagens in the kidney. The breakdown of collagen is affected by MMPs that in turn are influenced by TIMPs. The process may thereby be modulated at several points, each of which may affect the final outcome of the fibrous process in the kidney [72]. TIMPs are endogenous, specific inhibitors that bind and inhibit MMPs. Four TIMPs (TIMP-1-4) have been identified in vertebrates while TIMP-1, -2 , and -3 are all expressed in the kidney. TIMPs inhibit all MMPs, except TIMP-1, which does not inhibit MMP-14, -16, or -24 [73] .

TIMP-1 expression is universally upregulated in experimental kidney diseases along with increased interstitial fibrosis $[81,74,75]$. This pattern is also prominent in patients suffering from various acute or chronic conditions and CKD of various aetiology. Concerning acute conditions, urinary TIMP-1 concentration is primarily a marker of early kidney function in patients with kidney transplantation. As shown in a prospective cohort of 87 patients with kidney transplantation, urine TIMP-1 was increased on day 1 post surgery and values at 3 months were negatively correlated with creatinine clearance 2 years after transplantation [76]. Concerning CKD, almost three decades ago, increased TIMP-1 and -2 expression was found to be associated with glomerulosclerosis in humans [77] while urinary levels of TIMP-1 were increased in patients with CKD [78]. In another observational study of children with steroid dependent and steroid resistant nephrotic syndrome, urinary TIMP-1 levels were significantly higher in comparison to controls. Moreover, patients with steroid resistant forms of nephrotic syndrome had higher urinary TIMP-1/creatinine ratios as compared with steroid dependent patients [79]. Finally, in a study of 35 diabetic patients, TIMP1 expression was elevated in serum and urine with urinary TIMP-1 levels correlating with increased urine albumin [80]. 


\section{PROCOLLAGEN I ALPHA 1}

Renal fibrosis is the final common pathway of virtually all kidney diseases leading to chronic renal failure. Production and deposition of a large amount of ECM components are major cellular events of tubulointerstitial fibrosis in both animals and humans. Collagen type I, as well as fibronectin and type III collagens, are known as interstitial matrix components [81]. Collagen I is composed of two a 1 chains and one a 2 chain and is synthesized as a procollagen molecule [82]. Kidney fibrosis is partly attributed to an imbalance of collagen metabolism constituted of increased synthesis but also inhibition of breakdown. Interstitial fibrosis is mostly consisted of collagen-type-I-alpha-1 (co11a1) while the glomerular and vascular lesions are composed of collagen III and IV [83, 84].

There are only scarce data on the role and correlation of procollagen I alpha 1 in the progression of CKD. In experimental models of kidney fibrosis, as in cyclosporine treated rodents, both procollagen alpha $1 \mathrm{mRNA}$ levels and protein are significantly over expressed in the renal cortex in comparison to controls [85]. This finding is also confirmed in cultured proximal tubular cells and tubulointerstitial fibroblasts where cyclosporine can inhibit cell proliferation and stimulate procollagen alpha 1 transcription and synthesis [86]. Moreover, the increased expression and deposition of collagen type I alpha 1 in interstitial kidney fibrosis can be attributed to increased expression of procollagen-n-proteinase as it has been shown in the spontaneously hypertensive rat [87]. High levels of urinary procollagen type I have been associated with both cardiovascular disease and death in kidney transplant recipients [88]. Despite that, the importance of procollagen I alpha 1 excretion in urine as a marker of kidney disease progression has not been yet thoroughly evaluated in long prospective large cohorts of patients with CKD.

\section{SUPAR IN PROGRESSIVE CHRONIC KIDNEY DISEASE}

uPAR is a glycosyl-phosphatidyl-inositol (GPI)-anchored three-domain protein that has been shown to be a proteinase receptor for urokinase, but is also involved in other non-proteolytic pathways. It has been shown that uPAR is expressed in various cells and in the kidney its expression has been detected in tubular epithelial cells and podocytes. UPAR can be released from the plasma membrane as a soluble molecule (suPAR) by cleavage of the GPI anchor [89]. Elevated serum levels of suPAR have been reported under various disease conditions while in kidney diseases, Wei et al. [90] described that the serum levels of suPAR were elevated in $70 \%$ of FSGS patients and that the suPAR levels in FSGS patients were significantly higher than those in patients with other glomerulonephritides. In this study it was also demonstrated that circulating suPAR activated podocyte $\beta 3$ integrin, suggesting that suPAR might play a causal role in primary FSGS.

High plasma levels of suPAR in patients with normal kidney function have been associated with deterioration of kidney function [91]. In a study of 3682 patients the annual change of eGFR was $-4.2 \mathrm{ml} / \mathrm{min}$ in the highest quartile of plasma suPAR levels in comparison to $-0.9 \mathrm{ml} / \mathrm{min}$ in the lowest quartile. The most striking finding of this study was that this suPAR related decline in eGFR was higher in patients with a normal eGFR at baseline [74]. In another study of two unrelated cohorts of patients, it was shown that the decline in kidney function in high risk African American adult patients, that was attributed to APOL1 G1 and G2 gene variants, depended on high plasma suPAR levels [92]. This finding was ascribed to a synergistic mechanism due to high affinity protein-protein interaction of suPAR and APOL1 G1 or $\mathrm{G} 2$ risk variants proteins that leads to $\alpha \mathrm{v} \beta 3$ integrin activation on podocytes [75]. When SUPAR was compared to other cardiovascular disease biomarkers like high sensitivity CRP, troponin-I and heat shock protein 70, only suPAR was associated with future eGFR decline [93]. Nevertheless, in a cohort of patients with IgA nephropathy higher plasma suPAR levels were not correlated to a poor renal outcome although they were positively associated with proteinuria [94]. On the other hand, in a large cohort of Chinese patients with CKD due to glomerulonephritis, suPAR levels in the upper tertile were independently associated with an increased risk of progression to ESRD [95]. Finally, suPAR levels are higher in patients with type 1 diabetes and are associated with higher degrees of albuminuria in these patients [96]. 


\section{CKD273}

Urinary proteomics have also been utilized in the pursuit of earlier detection and risk stratification of CKD patients. CKD273 is a classifier that represents the combination of 273 urine peptides measured by coupled-mass spectrometry and found to differ significantly between patients with CKD of different causes and normal controls in a study from 2010 [97, 98]. CKD273 has since been validated in numerous studies. CKD273 is able to predict onset of diabetic nephropathy better than albuminuria [99] and is also able to foresee worsening of albuminuria in a study including 88 patients over a 3 year follow up period [100]. It is also worth mentioning that CKD273 seems to be able to provide information about which patients will not develop CKD over time, as exhibited in a prospective study with 53 patients by Argiles et al, where patients with $C K D 273<55$ did not reach end stage renal disease or die during the follow up period [101]. Moreover, the predictive advantage of CKD273 over albuminuria was also shown in a cohort of 2672 patients with CKD of different stages. These patients were divided according to baseline eGFR, and CKD273 and albuminuria were used to identify "progressors" (eGFR loss $>5 \mathrm{ml} / \mathrm{min} / 1.73 \mathrm{~m}^{2} /$ year). Whereas albuminuria prevailed in patients with advanced CKD, CKD273 exhibited significantly better performance in patients with early stages of CKD, a group where intervention is more likely to be beneficial [102]. Finally, CKD273 seems to be an efficient predictor of future kidney function deterioration in diabetics that develop CKD without the presence of remarkable albuminuria, a group of patients that has largely increased over the last decades [103, 104] .

\section{CONCLUSION}

We have reviewed nine of the most promising CKD biomarkers and all of them exhibit altered levels in the serum or urine in the presence of various kidney diseases, reduced eGFR and albuminuria. However, their utility as markers for risk of CKD progression is a completely different case. There are no data to support the use of Procollagen I alpha 1 and MMP-9 as markers of future progression of kidney disease. TIMP and $\mathrm{MCP}-1$ on the other hand, two proteins associated with interstitial inflammation and fibrosis, have exhibited value as prognostic biomarkers in cohorts of patients with IgAN (MCP-1) and in kidney transplant recipients (MCP-1 and TIMP). KIM-1 and NGAL are the most studied molecules and there are numerous studies linking them to deterioration of renal function. However, there is conflicting evidence, and even in cases that an association was seen, their use did not manage to improve model discrimination or risk reclassification. SuPAR is a promising molecule as well, especially, because its value was evident mainly in patients with normal renal function, the group of patients most suitable for intervention. To conclude, although there are molecules with promising results that warrant further investigation, by no means is there enough evidence to allow us to foresee displacement of the traditional biomarkers in the immediate future. $\mathrm{CKD}$ is not one disease but rather the common result of diverse disease processes that at times occur simultaneously, and no individual biomarker seems to invariably participate in all of them. This weakness of any separate biomarker could be the cause behind the impressive results achieved by CKD273, a tool encompassing numerous peptides that cover the entire spectrum of diverse pathophysiological pathways taking place in the kidneys. In any case, the increasing burden of CKD in our societies makes it imperative to carry on the effort to identify novel biomarkers in nephrology and data so far allow us to anticipate the emergence of them in the future.

\section{Disclosure}

All authors have nothing to disclose and have no conflicts of interest.

\section{REFERENCES}

1. Vasan RS. Biomarkers of cardiovascular disease: molecular basis and practical considerations. Circulation. 2006; 113: 2335-62

2. Biomarkers Definitions Working Group. Biomarkers and surrogate endpoints: preferred definitions and conceptual framework. Clin. Pharmacol. Ther. 2001; 69: 89-95

3. Coresh J, Selvin E, Stevens LA et al. Prevalence of chronic kidney disease in the United States. JAMA. 2007; 298(17): 2038-47 
4. Goodsaid FM, Blank M, Dieterle F et al. Novel biomarkers of acute kidney toxicity. Clin Pharmacol Ther. 2009; 86(5): 490-6.

5. Goumenos DS, Tsamandas AC, Oldroyd S et al. Transforming growth factor-beta (1) and myofibroblasts: a potential pathway towards renal scarring in human glomerular disease. Nephron. 2001; 87(3): 240-8.

6. Goumenos DS, Kalliakmani P, Tsakas S, Papachristou E, Vlachojannis JG. Growth factors and apoptosis-related protein expression in human crescentic nephritis. Med Sci Monit. 2008; 14: 243-48.

7. Papasotiriou M, Kalliakmani P, Huang L et al. Does treatment with corticosteroids and cyclosporine reduce transglutaminase type 2 expression in the renal tissue of patients with membranous nephropathy? Nephron Clin Pract. 2012; 121: 60-7.

8. Goumenos DS, Brown CB, Shortland J, el Nahas AM. (1994) Myofibroblasts, predictors of progression of mesangial IgA nephropathy? Nephrol. Dial. Transplant. 1994; 9: 1418-25.

9. Ichimura T, Bonventre JV, Bailly V et al. Kidney injury molecule-1 (KIM-1), a putative epithelial cell adhesion molecule containing a novel immunoglobulin domain, is up-regulated in renal cells after injury. J. Biol. Chem. 1998; 273: 4135-42.

10. Ismail O, Zhang X, Bonventre JV, Gunaratnam L. G protein $\alpha 12(\mathrm{G \alpha} 12)$ is a negative regulator of kidney injury molecule-1-mediated efferocytosis. Am. J. Phys. Renal Phys. 2016; 310: 607-20

11. Yin C, Wang N. Kidney injury molecule-1 in kidney disease, Ren. Fail. 2016; 38: 1567-73.

12. Zhang Z, Humphreys BD, Bonventre JV. Shedding of the urinary biomarker kidney injury molecule-1 (KIM-1) is regulated by MAP kinases and juxtamembrane region. J. Am. Soc. Nephrol. 2007; 18: 2704-14.

13. Prozialeck WC, Vaidya VS, Liu J et al. Kidney injury molecule- 1 is an early biomarker of cadmium nephrotoxicity. Kidney Int. 2007; 72: 985-93.

14. Lim AI, Chan LY, Lai KN et al. Distinct role of matrix metalloproteinase-3 in kidney injury molecule- 1 shedding by kidney proximal tubular epithelial cells. Int. J. Biochem. Cell Biol. 2012; 44: 1040-50.

15. Bailly V, Zhang Z, Meier W et al. Shedding of kidney injury molecule-1, a putative adhesion protein involved in renal regeneration. J. Biol. Chem. 2002; 277: 39739-48.

16. Lim AI, Tang SC, Lai KN, Leung JC. Kidney injury molecule-1: more than just an injury marker of tubular epithelial cells? J. Cell. Physiol. 2013; 228: 917-24.

17. Han WK, Bailly V, Abichandani R et al. Kidney Injury Molecule-1 (KIM-1): a novel biomarker for human renal proximal tubule injury. Kidney Int. 2002; 62: 237-44.

18. Ichimura T, Hung CC, Yang SA et al. Kidney injury molecule-1: a tissue and urinary biomarker for nephrotoxicant-induced renal injury. Am. J. Phys. Renal Phys. 2004; 286: 552-63.

19. Bonventre JV, Yang L. Kidney injury molecule-1. Curr. Opin. Crit. Care. 2010; 16: 556-61.

20. Vaidya VS, Ozer JS, Dieterle F et al. Kidney injury molecule-1 outperforms traditional biomarkers of kidney injury in preclinical biomarker qualification studies. Nat. Biotechnol. 2010; 28: 478-85.

21. van Timmeren MM, van den Heuvel MC, Bailly V, Bakker SJ, van Goor H, Stegeman CA. Tubular kidney injury molecule-1 (KIM-1) in human renal disease. J. Pathol. 2007; 212: 209-17.

22. Schröppel B, Krueger B, Walsh L et al. Tubular expression of KIM-1 does not predict delayed function after transplantation. J. Am. Soc. Nephrol. 2010; 21: 536-42.

23. Wasung ME, Chawla LS, Madero M. Biomarkers of renal function, which and when? Clin. Chim. Acta. 2015; 438: 350-57.

24. De Silva PMCS, Mohammed Abdul KS, Eakanayake EM et al. Urinary biomarkers KIM-1 and NGAL for detection of chronic kidney disease of uncertain etiology (CKDu) among agricultural communities in Sri Lanka. PLoS Negl. Trop. Dis. 2016;10:e0004979

25. Castillo-Rodriguez E, Fernandez-Prado R, Martin-Cleary $\mathrm{C}$ et al. Kidney injury marker 1 and neutrophil gelatinase associated lipocalin in chronic kidney disease. Nephron. 2017; 136: 263-67.

26. Nasioudis D, Witkin SS: Neutrophil gelatinase-associated lipocalin and innate immune responses to bacterial infections. Med Microbiol Immunol. 2015; 204: 471-79.

27. Kuncio, G.S.; Neilson, E.G.; Haverty, T. Mechanisms of tubulointerstitial fibrosis. Kidney Int. 1991; 39: 550-56.

28. Viau A, Karoui KE, Laouari D et al. Lipocalin 2 is essential for chronic kidney disease in mice and human. J. Clin. Investig. 2010; 120: 4065-76.

29. Dubin RF, Judd S, Scherzer R et al. Urinary Tubular Injury Biomarkers Are Associated With ESRD and Death in the REGARDS Study. Kidney Int Rep. 2018; 3(5): 1183-92.

30. Seibert FS, Sitz M, Passfall J et al. Prognostic Value of Urinary Calprotectin, NGAL and KIM1. Chronic Kidney Disease. Kidney Blood Press Res. 2018; 43(4): 1255-62.

31. Ding Y, Nie LM, Pang Y et al. Composite urinary biomarkers to predict pathological tubulointerstitial lesions in lupus nephritis. Lupus. 2018; 27(11): 1778-89.

32. Alderson HV, Ritchie JP, Pagano S et al. The Associations of Blood Kidney Injury Molecule-1 
and Neutrophil Gelatinase-Associated Lipocalin with Progression from CKD to ESRD. Clin J Am Soc Nephrol. 2016; 11(12): 2141-49.

33. De Carvalho JA, Tatsch E, Hausen BS et al. Urinary kidney injury molecule-1 and neutrophil gelatinase-associated lipocalin as indicators of tubular damage in normoalbuminuric patients with type 2 diabetes. Clinical Biochemistry. 2016; 49(3): 232-36.

34. Satirapoj B, Aramsaowapak K, Tangwonglert T, Supasyndh O. Novel tubular biomarkers predict renal progression in type 2 diabetes mellitus: a prospective cohort study. J Diabetes Res. 2016; 2016: 3102962.

35. Nielsen SE, Reinhard H, Zdunek D et al. Tubular markers are associated with decline in kidney function in proteinuric type 2 diabetic patients. Diabetes Res Clin Pract. 2012; 97(1): 71-6.

36. Panduru NM, Sandholm N, Forsblom C et al. Kidney injury molecule- 1 and the loss of kidney function in diabetic nephropathy: a likely causal link in patients with type 1 diabetes. Diabetes Care. 2015; 38(6): 1130-37.

37. Smith ER, Lee D, Cai M et al. Urinary neutrophil gelatinase-associated lipocalin may aid prediction of renal decline in patients with non-proteinuric stages 3 and 4 chronic kidney disease. Nephrol Dial Transplant. 2013; 28: 1569-79.

38. Bolignano D, Lacquaniti A, Coppolino $G$ et al. Neutrophil gelatinase-associated lipocalin (NGAL) and progression of chronic kidney disease. Clin J Am Soc Nephrol. 2009; 4: 337-44.

39. Mitsnefes MM, Kathman TS, Mishra J et al. Serum neutrophil gelatinase-associated lipocalin as a marker of renal function in children with chronic kidney disease. Pediatr Nephrol. 2007; 22(1): $101-8$.

40. Cochran BH, Reffel AC, Stiles CD. Molecular cloning of gene sequences regulated by platelet-derived growth factor. Cell. 1983; 33: 939-47

41. Van Coillie E, Van Damme J, Opdenakker G. The $\mathrm{MCP} /$ eotaxin subfamily of CC chemokines. $\mathrm{Cy}$ tokine Growth Factor Rev. 1999; 10: 61-86.

42. Cushing SD, Berliner JA, Valente AJ et al. Minimally modified low density lipoprotein induces monocyte chemotactic protein 1 in human endothelial cells and smooth muscle cells. Proc Natl Acad Sci USA. 1990; 87: 5134-38.

43. Leonard EJ, Yoshimura T. Human monocyte chemoattractant protein-1 (MCP-1). Immunol Today. 1990; 11: 97-101.

44. Morii T, Fujita H, Narita T et al. Increased urinary excretion of monocyte chemoattractant protein-1 in proteinuric renal diseases. Ren Fail. 2003; 25(3): 439-44.

45. Segarra-Medrano A, Carnicer-Caceres C, Valtierra-Carmeno $\mathrm{N}$ et al. Value of urinary levels of interleukin-6, epidermal growth factor, monocyte chemoattractant protein type 1 and transforming growth factor $\beta 1$ in predicting the extent of fibrosis lesions in kidney biopsies of patients with $\operatorname{Ig} \mathrm{A}$ nephropathy. Nefrologia. 2017; 37(5): 531-38.

46. Worawichawong S, Worawichawong S, Radinahamed $\mathrm{P}$ et al. Urine Epidermal Growth Factor, Monocyte Chemoattractant Protein-1 or their Ratio as Biomarkers for Interstitial Fibrosis and Tubular Atrophy in Primary Glomerulonephritis. Kidney Blood Press Res. 2016; 41(6): 997-1007.

47. Dantas M, Romão EA, Costa RS et al. Urinary excretion of monocyte chemoattractant protein-1: a biomarker of active tubulointerstitial damage in patients with glomerulopathies. Kidney Blood Press Res. 2007; 30(5): 306-13.

48. Wang X, Lieske JC, Alexander MP et al. Tubulointerstitial fibrosis of living donor kidneys associates with urinary monocyte chemoattractant protein. Am J Nephrol. 2016; 43(6): 454-59.

49. Ho J, Rush DN, Gibson IW et al. Early urinary CCL2 is associated with the later development of interstitial fibrosis and tubular atrophy in renal allografts. Transplantation. 2010; 90(4): 394-400.

50. Ho J, Wiebe C, Gibson IW et al. Elevated Urinary CCL2: $\mathrm{Cr}$ at 6 months is associated with renal allograft interstitial fibrosis and inflammation at 24 months. Transplantation. 2014; 98(1): 39-46

51. de Boer IH, Gao X, Bebu I et al. Biomarkers of tubulointerstitial damage and function in type 1 diabetes. BMJ Open Diabetes Res Care. 2017; 5(1):e000461.

52. Zeng XF, Lu DX, Li JM et al. Performance of urinary neutrophil gelatinase-associated lipocalin, clusterin, and cystatin $\mathrm{C}$ in predicting diabetic kidney disease and diabetic microalbuminuria: a consecutive cohort study. BMC Nephrol. 2017; 18(1): 233.

53. Hidaka S, Kränzlin B, Gretz N, Witzgall R. Urinary clusterin levels in the rat correlate with the severity of tubular damage and may help to differentiate between glomerular and tubular injuries. Cell and Tissue Research, 2002; 310(3): 289-96.

54. Dvergsten J, Manivel JC, Correa-Rotter R, Rosenberg ME. Expression of clusterin in human renal diseases. Kidney Int. 1994; 45(3): 828-35.

55. Mohamed F, Buckley NA, Pickering JW et al. Nephrotoxicity-induced proteinuria increases biomarker diagnostic thresholds in acute kidneyinjury. BMC Nephrol. 2017; 18(1): 122. doi: 10.1186/s12882-017-0532-7.

56. Askenazi DJ, Koralkar R, Patil N, Halloran B, Ambalavanan N, Griffin R. Acute Kidney Injury urine biomarkers in very low-birth-weight infants. Clin J Am Soc Nephrol. 2016; 11(9): 1527-35.

57. Rouse RL, Zhang J, Stewart SR, Rosenzweig BA, Espandiari P, Sadrieh NK.. Comparative profile of commercially available urinary biomarkers in 
preclinical drug-induced kidney injury and recovery in rats. Kidney Int. 2011; 79(11): 1186-97.

58. Cho Y, Johnson DW, Vesey DA, Hawley CM, Clarke M, Topley N; balANZ Trial Investigators. Utility of urinary biomarkers in predicting loss of residual renal function: The balANZ Trial. Perit Dial Int. 2015; 35(2): 159-71.

59. Singhal MK, Bhaskaran S, Vidgen E, Bargman JM, Vas SI, Oreopoulos DG. Rate of decline of residual renal function in patients on continuous peritoneal dialysis and factors affecting it. Perit Dial Int. 2000; 20(4): 429-38.

60. Hallan SI, Ritz E, Lydersen S, Romundstad S, Kvenild K, Orth SR. Combining GFR and albuminuria to classify CKD improves prediction of ESRD. J Am Soc Nephrol 2009; 20(5): 1069-77.

61. Kim SS, Song SH, Kim JH et al. Urine clusterin/ apolipoprotein $\mathrm{J}$ is linked to tubular damage and renal outcomes in patients with type 2 diabetes mellitus. Clin Endocrinol (Oxf). 2017; 87(2): 156-64.

62. Zeng XF, Lu DX, Li JM et al. Performance of urinary neutrophil gelatinase-associated lipocalin, clusterin, and cystatin $\mathrm{C}$ in predicting diabetic kidney disease and diabetic microalbuminuria: a consecutive cohort study. BMC Nephrol. 2017; 18(1): 233.

63. Lindsey ML, Iyer RP, Jung M, DeLeon-Pennell KY, Ma Y. Matrix Metalloproteinases as input and output signals for post-myocardial infarction remodeling. J Mol Cell Cardiol. 2016; 91: 134-40.

64. Tan RJ, Liu Y. Matrix metalloproteinases in kidney homeostasis and diseases. Am J Physiol Renal Physiol. 2012; 302(11): 1351-61.

65. Ke B, Fan C, Yang L, Fang X. Matrix Metalloproteinases-7 and kidney fibrosis. Front Physiol. 2017; 8: 21.

66. Urushihara M, Kagami S, Kuhara T, Tamaki T, Kuroda Y. Glomerular distribution and gelatinolytic activity of matrix metalloproteinases in human glomerulonephritis. Nephrol Dial Transplant. 2002; 17(7): 1189-96.

67. Erol M, Yigit $\mathrm{O}$, Tasdemir $\mathrm{M}$ et al. Potential of serum and urinary Matrix Metalloproteinase-9 levels for the early detection of renal involvement in children with Henoch-Schönlein Purpura. Iran J Pediatr. 2016; 26(4): 6129.

68. Musiał K, Bargenda A, Zwolińska D. Urine matrix metalloproteinases and their extracellular inducer EMMPRIN in children with chronic kidney disease. Ren Fail. 2015; 37(6): 980-4.

69. van der Zijl NJ, Hanemaaijer R, Tushuizen ME et al. Urinary matrix metalloproteinase- 8 and -9 activities in type 2 diabetic subjects: A marker of incipient diabetic nephropathy? Clin Biochem. 2010; 43(7-8): 635-9.

70. Sanders JS, Huitema MG, Hanemaaijer R, van Goor H, Kallenberg CG, Stegeman CA. Urinary matrix metalloproteinases reflect renal damage in anti-neutrophil cytoplasm autoantibody-associated vasculitis. Am J Physiol Renal Physiol. 2007; 293(6): 1927-34.

71. Korzeniecka-Kozerska A, Wasilewska A, Tenderenda E, Sulik A, Cybulski K. Urinary MMP-9/ NGAL ratio as a potential marker of FSGS in nephrotic children. Dis Markers. 2013; 34(5): 357-62.

72. Hultström M, Leh S, Skogstrand T, Iversen BM. Upregulation of tissue inhibitor of metalloproteases-1 (TIMP-1) and procollagen-N-peptidase in hypertension-induced renal damage. Nephrol Dial Transplant. 2008; 23(3): 896-903.

73. Catania JM, Chen G, Parrish AR. Role of matrix metalloproteinases in renal pathophysiologies. Am J Physiol Renal Physiol. 2007; 292(3): 9 05-11.

74. Duymelinck C, Dauwe SE, De Greef KE, Ysebaert DK, Verpooten GA, De Broe ME. TIMP-1 gene expression and PAI-1 antigen after unilateral ureteral obstruction in the adult male rat. Kidney Int. 2000; 58(3): 1186-201.

75. Han SY, Jee YH, Han KH et al. An imbalance between matrix metalloproteinase- 2 and tissue inhibitor of matrix metalloproteinase-2 contributes to the development of early diabetic nephropathy. Nephrol Dial Transplant. 2006; 21(9): 2406-16.

76. Kwiatkowska E, Domanski L, Bober J et al. Urinary Metalloproteinases-9 and -2 and Their Inhibitors TIMP-1 and TIMP-2 are Markers of Early and Long-Term Graft Function After Renal Transplantation. Kidney Blood Press Res. 2016; 41(3): 288-97.

77. Vanden Heuvel GB, Abrahamson DR. Quantitation and localization of laminin A, B1, and B2 chain RNA transcripts in developing kidney. Am J Physiol. 1993; 265(2 Pt 2): 293-9.

78. Hörstrup JH, Gehrmann M, Schneider B et al. Elevation of serum and urine levels of TIMP- 1 and tenascin in patients with renal disease. Nephrol Dial Transplant. 2002; 17(6): 1005-13.

79. Bieniaś B, Sikora P. Urinary metalloproteinases and tissue inhibitors of metalloproteinases as potential early biomarkers for renal fibrosis in children with nephrotic syndrome. Medicine (Baltimore). 2018; 97(8): e9964.

80. Kanauchi M, Nishioka H, Nakashima Y, Hashimoto T, Dohi K. Role of tissue inhibitors of metalloproteinase in diabetic nephropathy. Nihon Jinzo Gakkai Shi. 1996; 38(3): 124-8.

81. Li L, Shen Y, Ding Y, Liu Y, Su D, Liang X. Hrd1 participates in the regulation of collagen I synthesis in renal fibrosis. Mol Cell Biochem. 2014; 386(1-2): 35-44.

82. Myllyharju J, Kivirikko KI. Collagens, modifying enzymes and their mutations in humans, flies and worms. Trends Genet. 2004; 20(1): 33-43.

83. Cheng HF, Wang JL, Zhang MZ, McKanna JA, Harris RC. Nitric oxide regulates renal cortical 
cyclooxygenase-2 expression. Am J Physiol Renal Physiol. 2000; 279(1): 122-9.

84. Tharaux PL, Chatziantoniou C, Casellas D, Fouassier L, Ardaillou R, Dussaule JC. Vascular endothelin-1 gene expression and synthesis and effect on renal type I collagen synthesis and nephroangiosclerosis during nitric oxide synthase inhibition in rats. Circulation. 1999; 99(16): 2185-91.

85. Nast CC, Adler SG, Artishevsky A, Kresser CT, Ahmed K, Anderson PS. Cyclosporine induces elevated procollagen alpha 1 (I) mRNA levels in the rat renal cortex. Kidney Int. 1991; 39(4): 631-8.

86. Wolf G, Killen PD, Neilson EG. Cyclosporin A stimulates transcription and procollagen secretion in tubulointerstitial fibroblasts and proximal tubular cells. J Am Soc Nephrol. 1990; 1(6): 918-22.

87. Hultström M, Leh S, Skogstrand T, Iversen BM. Upregulation of tissue inhibitor of metalloproteases-1 (TIMP-1) and procollagen-N-peptidase in hypertension-induced renal damage. Nephrol Dial Transplant. 2008; 23(3): 896-903.

88. Park M, Katz R, Shlipak MG et al. Urinary markers of fibrosis and risk of cardiovascular events and death in kidney transplant recipients: The FAVORIT Trial. Am J Transplant. 2017; 17(10): 2640-49.

89. Wada T, Nangaku M. A circulating permeability factor in focal segmental glomerulosclerosis: the hunt continues. Clin Kidney J. 2015; 8(6): 708-15.

90. Wei C, Trachtman H, Li J et al.. Circulating suPAR in two cohorts of primary FSGS .J Am Soc Nephrol. 2012; 23(12): 2051-9.

91. Hayek SS, Sever S, Ko YA et al. Soluble urokinase receptor and chronic kidney disease. N Engl J Med. 2015; 373(20): 1916-25.

92. Hayek SS, Koh KH, Grams ME et al. A tripartite complex of suPAR, APOL1 risk variants and $\alpha v \beta 3$ integrin on podocytes mediates chronic kidney disease. Nat Med. 2017; 23(8): 945-53.

93. Hayek SS, Ko YA, Awad M et al. Cardiovascular disease biomarkers and suPAR in predicting decline in renal function: A Prospective Cohort Study. Kidney Int Rep. 2017; 2(3): 425-32.
94. Zhao Y, Liu L, Huang J et al. Plasma soluble urokinase receptor level is correlated with podocytes damage in patients with IgA nephropathy. PLoS One. $2015 ;$ 10(7): e0132869

95. Lv L, Wang F, Wu L et al. Soluble urokinase-type plasminogen activator receptor and incident end-stage renal disease in Chinese patients with chronic kidney disease. Nephrol Dial Transplant. 2018 Aug 13. doi: 10.1093/ndt/gfy265.

96. Theilade S, Lyngbaek S, Hansen TW et al. Soluble urokinase plasminogen activator receptor levels are elevated and associated with complications in patients with type 1 diabetes. J Intern Med. 2015; 277(3): 362-71.

97. Good DM, Zürbig P, Argiles A et al. Naturally occurring human urinary peptides for use in diagnosis of chronic kidney disease. Mol Cell Proteomics. 2010; 9(11): 2424-37.

98. Pejchinovski M., Mischak H. Clinical proteomics in kidney disease: from discovery to clinical application. Prilozi. 2017; 38(3): 39-54.

99. Zürbig $P$, Jerums $G$, Hovind $P$ et al. Urinary Proteomics for Early Diagnosis in Diabetic Nephropathy. Diabetes. 2012; 61(12): 3304-13.

100. Roscioni SS, de ZD, Hellemons ME et al. A urinary peptide biomarker set predicts worsening of albuminuria in type 2 diabetes mellitus. Diabetologia. 2012; 56(2): 259-67.

101. Argiles A, Siwy J, Duranton F et al. CKD273, a New Proteomics Classifier Assessing CKD and Its Prognosis. PLoS One. 2013; 8(5): e62837

102. Pontillo C, Jacobs L, Staessen JA et al. A Urinary proteome-based Classifier for the early Detection of Decline in Glomerular Filtration. Nephrol Dial Transplant. 2017; 32(9): 1510-16.

103. Kramer H, Boucher RE, Leehey D et al. Increasing mortality in adults with diabetes and low estimated glomerular filtration rate in the absence of albuminuria. Diabetes Care. 2018; 41(4): 775-81.

104. Zürbig P, Mischak H, Menne J, Haller H. CKD273 enables efficient prediction of diabetic nephropathy in nonalbuminuric patients. Diabetes Care. 2019; 42(1): e4-e5. doi: 10.2337/dc18-1322. 


\section{Резиме}

БИОМАРКЕРИ КАЈ ПРОГРЕСИВНА ХРОНИЧНА БУБРЕЖНА БОЛЕСТ. ПРЕТСТОИ УШТЕ РАБОТА

\section{Теодорос Нтриниас, Мариос Папасотириу, Ламприни Мпалта, Димитра Калавризиоти, Сотириос Вамвакас, Евангелос Папахристу, Димитриос С. Гуменос}

Оддел за нефрологија и бубрежна трансплантација, Универзитетска болница Патра, Патра, Грција

Традиционалните биомаркери за хронична бубрежна болест (ХББ) (eGFR заснован на серумски креатинин, пол и возраст и албуминурија) не можат да го предвидат индивидуалниот ризик на пациентот за развивање прогресивна ХББ. Поради ова, неопходно е да се идентификуваат нови биомаркери за ХББ, кои ќе можат да предвидат кои пациенти се склони да развијат прогресивна болест и да прават разлика меѓу процесите на болеста во различни делови на нефронот (гломерули или тубули).

Добриот биомаркер треба да се промени пред или истовремено со развојот на лезиите и неговите промени треба да бидат во силна корелација со развојот на лезиите. Исто така, треба да постои тесна врска меѓу сериозноста на повредата и количината на забележлив биомаркер, а неговите нивоа треба да се намалат со намалувањето на повредата.

Од големиот број молекули што се испитуваат, ги прегледавме најперспективните: NGAL и KIM-1, MCP-1, MMP-9, кластерин, MMP-9, TIMP-1, Procollagen I alpha 1 и suPAR. Сите овие се изучувани како биомаркери за предвидување на прогресијата на ХББ кај групи пациенти со хронична бубрежна болест од различни фази и разни етиологии (протеинурични и непротеинтриурни, гломерулонефритиди, дијабетични, хипертензивни и полицистични заболувања на бубрезите). Постојат докази дека овие молекули можат да бидат корисни како биомаркери за прогресивна хронична бубрежна болест, меѓутоа, достапните податоци не се доволни за да се извлечат конечни заклучоци. Потребни се дополнителни студии со големи групи и долго следење за да се идентификуваат соодветни биомаркери што ќе можат точно и сигурно да го дефинираат ризикот за прогресивната хронична бубрежна болест.

Клучни зборови: хронична бубрежна болест, биомаркери, интерстицијална фиброза 